УДК 576.53:[611.018.26+616.419+616.127]: 576.32 DOI 10.31210/visnyk2018.03.22

(C) 2018

\author{
Мазуркевич А. Й., доктор ветеринарних наук, \\ Ковпак В. В., кандидат ветеринарних наук, \\ Ковпак O. C., аспірант \\ (науковий керівник - доктор ветеринарних наук А. Й. Мазуркевич)
}

Національний університет біоресурсів і природокористування України

\title{
ВПЛИВ ГОРМОНУ РОСТУ (RHGH) ТА ВIOLAMININ 521 LN HA ПРОЛІФЕРАТИВНУ АКТИВНІСТЬ СТОВБУРОВИХ КЛІТИН КОТА
}

\section{Рецензент - доктор ветеринарних наук, професор М. О. Малюк}

\begin{abstract}
Досліджено вплив гормону росту (rhGH) у різних конщентраціях та Biolaminin 521 LN на проліферативну активність та генетичну стабільність стовбурових клітин, отриманих з кісткового мозку, жирової тканини та міокарду кота. Встановлено, щзо гормон росту у низьких конщентраціях (10 нг/мл) позитивно впливає на проліферативну активність стовбурових клітин, отриманих із жирової тканини та міокарду кота. Разом із тим, на культуру стовбурових клітин кісткового мозку ефект низьких концентрацій rhGH був протилежний. Культивування стовбурових клітин за додавання Biolaminin 521 LN nризвело до достовірного збільшення індексу проліфераиії у всіх досліджуваних культурах. За даними цитогенетичного аналізу встановлено, щзо додавання гормону росту у культуральне середовище не призводить до достовірного збільшення кількості генетичних помилок. Водночас, додавання Biolaminin 521 LN призводить до зменшення кількості клітин із зміненим каріотипом (у порівнянні з контролем) у всіх досліджуваних культурах.
\end{abstract}

Ключові слова: гормон росту (rhGH), Biolaminin 521 LN, стовбурові клітини, культура клітин кісткового мозку, культура клітин жирової тканини, культура клітин міокарда, коти, цитогенетичний аналіз.

Постановка проблеми. За останні 50 років виконана значна кількість експериментальних досліджень, які вирішують різні проблеми клітинних технологій. Опубліковано сотні робіт, які вказують на позитивні результати використання стовбурових клітин (СК) при різноманітних захворюваннях $[2,16]$. Проте успішне використання клітинних технологій у ветеринарній медицині в значній мірі залежать від результатів грунтовного вивчення властивостей стовбурових клітин тварин.

Аналіз основних досліджень і публікацій, у яких започатковано розв'язання проблеми. Незважаючи на чисельні публікації у світі щодо властивостей стовбурових клітин, досліджень із цього питання у ветеринарній медицині України обмаль $[1,3,4,5]$. А дані щодо використання стовбурових клітин при терапії патологій серцевого м'яза взагалі відсутні у доступних нам літературних джерелах.

Варто зазначити, що кістковий мозок на сьогоднішній день $є$ найбільш вивченим джерелом стовбурових клітин дорослого організму. Серед клітин, які містяться у кістковому мозку та здатні до поділу в умовах in vitro, виділяють: гемопоетичні стовбурові клітини (ГСК) [19], мезенхімальні стовбурові клітини (МСК) [19], ендотеліальні клітини-попередниці [18], плюрипотентні [22] та мультипотентні [11] стовбурові клітини.

Проте останнім часом увагу науковців привернуло альтернативне джерело отримання стовбурових клітин: жирова тканина. 3 неї виділяють гемопоетичні стовбурові клітини [15], мезенхімальні стовбурові клітини [17] та ендотеліальні клітини-попередниці [23], преадипоцити [20]. Однак не варто забувати про органоспецифічні стовбурові клітини, якими є стовбурові клітини серця [7].

Використання клітинних технологій у клінічній практиці потребує великої кількості клітинного матеріалу. Це, у свою чергу, спонукає до розробки методів, які дозволять отримати більшу кількість клітинного матеріалу за менший проміжок часу. 3 літературних даних відомо, що гормону росту [21] та Biolaminin 521 LN [12] здатні позитивно впливати на мітотичну активність стовбурових клітин.

Зважаючи на відмінності клітинного складу культур, отриманих із різних тканин, різним буде i вплив rhGH та Biolaminin 521 LN на їх проліферативну активність.

Тому нашою метою було дослідити вплив rhGH у різних концентраціях та Biolaminin 521 LN на проліферативну активність стовбурових клітин, отриманих із кісткового мозку, жирової тканини та міокарду кота. 


\section{ВЕТЕРИНАРНА МЕДИЦИНА}

Завдання: отримати культури стовбурових клітин кісткового мозку, жирової тканини та міокарда кота; дослідити вплив гормону росту та Biolaminin 521 LN на проліферативну активність вказаних культур; дослідити генетичну стабільність досліджуваних культур клітин залежно від проліферативної активності клітин.

Матеріали і методи дослідження. У досліді для отримання культур клітин використовували жирову тканину, кістковий мозок та тканину міокарда котів. Всі маніпуляції з тваринами здійснювалися за попередньої згоди господарів та 3 дотриманням вимог Закону України «Про захист тварин від жорстокого поводження» (ст. 230 від 2006 року).

Отримання культури стовбурових клітин жирової тканини (КСКЖТ) здійснювали 3 підшкірної жирової клітковини дорослих кішок під час планової гістеректомії за стандартною методикою [14] у власній модифікації. Культуру стовбурових клітин кісткового мозку (КСККМ) отримували з кісткового мозку переважно стегнових кісток дорослих котів за стандартною методикою $[14,6]$. Культуру стовбурових клітин міокарда (КСКМ) отримували із серця завмерлих плодів кошенят, що залишалися після надання пологодопомоги модифікованим методом експланту [14].

Одержану клітинну масу культивували у стандартному середовищі: 80 \% - DMEM; $20 \%-$ FBS; 10 мкл/см ${ }^{3}$ - антибіотика-антимікотика («Sigma», США); у $\mathrm{CO}_{2}$-інкубаторі за $37{ }^{\circ} \mathrm{C}$ та $5 \%$ концентрації $\mathrm{CO}_{2}$ [6], до конфлюентності 90-100\%. Клітини знімали за стандартною методикою (0,25 \% розчином трипсину/ЕДТА) [6].

У дослідах використовували стовбурові клітини III пасажу. Пасажування здійснювали у співвідношенні 1:5. Клітини культивували у стандартному середовищі: 80 \% - DMEM; $20 \%-$ FBS; 10 мкл/см ${ }^{3}$ - антибіотика-антимікотика («Sigma», США) з додаванням:

1) rhGH («Sigma», США) у концентрації 10; 20 та 50 нг/мл;
2) Biolaminin 521 LN (LN521) («BioLamina», Швейцарія) згідно настанов виробника;

3) контроль (культивування у стандартному культуральному середовищі).

Підрахунок кількості клітин здійснювали після досягнення конфлюентності 90-100\% у одній iз досліджуваних груп чашок (КСККМ - 2-га доба, КСКЖТ - 3-тя доба, КСКМ - 2-га доба). Додатково визначали індекс проліферації:

$$
\text { III }=\frac{\Pi n}{\Pi k} \times 100 \%
$$

де: ІП - індекс проліферації;

ПП - кількість клітин після пасажування;

ПК - посадкова кількість клітин.

Мікроскопічний аналіз і оцінку культур здійснювали за допомогою інвертованого мікроскопа «Axiovert 40» (Карл Цейс).

Результати досліджень. У процесі нашого дослідження ми відмічали відмінності у впливі різних мітогенів на проліферативну активність клітин у культурі.

Так, за додавання rhGH до культурального середовища 3 КСККМ ми відмічали зниження індексу проліферації нижче контролю, причому спостерігали кореляцію між збільшенням концентрації гормону та зменшенням індексу проліферації (табл. 1). При додаванні 10 нг/мл rhGH до КСКЖТ та КСКМ відмічали збільшення індексу проліферації у 1,2 та 1,3 рази відповідно (табл. 1). Проте зі збільшенням концентрації гормону у середовищі індекс проліферації також знижувався. Варто відмітити, що клітини за додавання rhGH були візуально більші порівняно 3 клітинами у контрольній групі чашок (рис. 1).

Гормон росту сприяє синтезу білка, мобілізації ліпідного обміну та регулює баланс азоту у клітині [8]. Додатково, за даними Costoya J.A. [9], гормон росту здатний гальмувати апоптоз шляхом стимуляції серин-треонін кінази Akt, тому можна припустити, що це призводить до появи у культурі великих за розмірами клітин.

\section{1. Залежність проліферативної активності стовбурових клітин, отриманих із різних джерел,}

від концентрації $r h G H(M \pm m, n=3)$

\begin{tabular}{|c|c|c|c|c|}
\hline \multirow{3}{*}{ Культура клітин } & \multicolumn{3}{|c|}{ Концентрація rhGH у культуральному середовищі } & \multirow{2}{*}{ Контроль } \\
\hline & 10 нг/МЛ & $20 \mathrm{Hг} / \mathrm{MЛ}$ & $50 \mathrm{нг} / \mathrm{MЛ}$ & \\
\hline & \multicolumn{4}{|c|}{ Індекс проліферації } \\
\hline КСККМ & $1,22 \pm 0,04 * *$ & $1,09 \pm 0,04 * * *$ & $0,88 \pm 0,04 * * *$ & $1,44 \pm 0,05$ \\
\hline КСКЖТ & $2,39 \pm 0,06$ & $2,08 \pm 0,05$ & $1,05 \pm 0,06^{* *}$ & $1,85 \pm 0,11$ \\
\hline КСКМ & $2,36 \pm 0,07 * *$ & $2,20 \pm 0,08^{* *}$ & $2,07 \pm 0,04^{*}$ & $1,81 \pm 0,10$ \\
\hline
\end{tabular}

Примітка: ${ }^{*} \mathrm{p}<0,05 ; * *_{\mathrm{p}}<0,01 ; * * * \mathrm{p}<0,001$ порівняно з контролем 

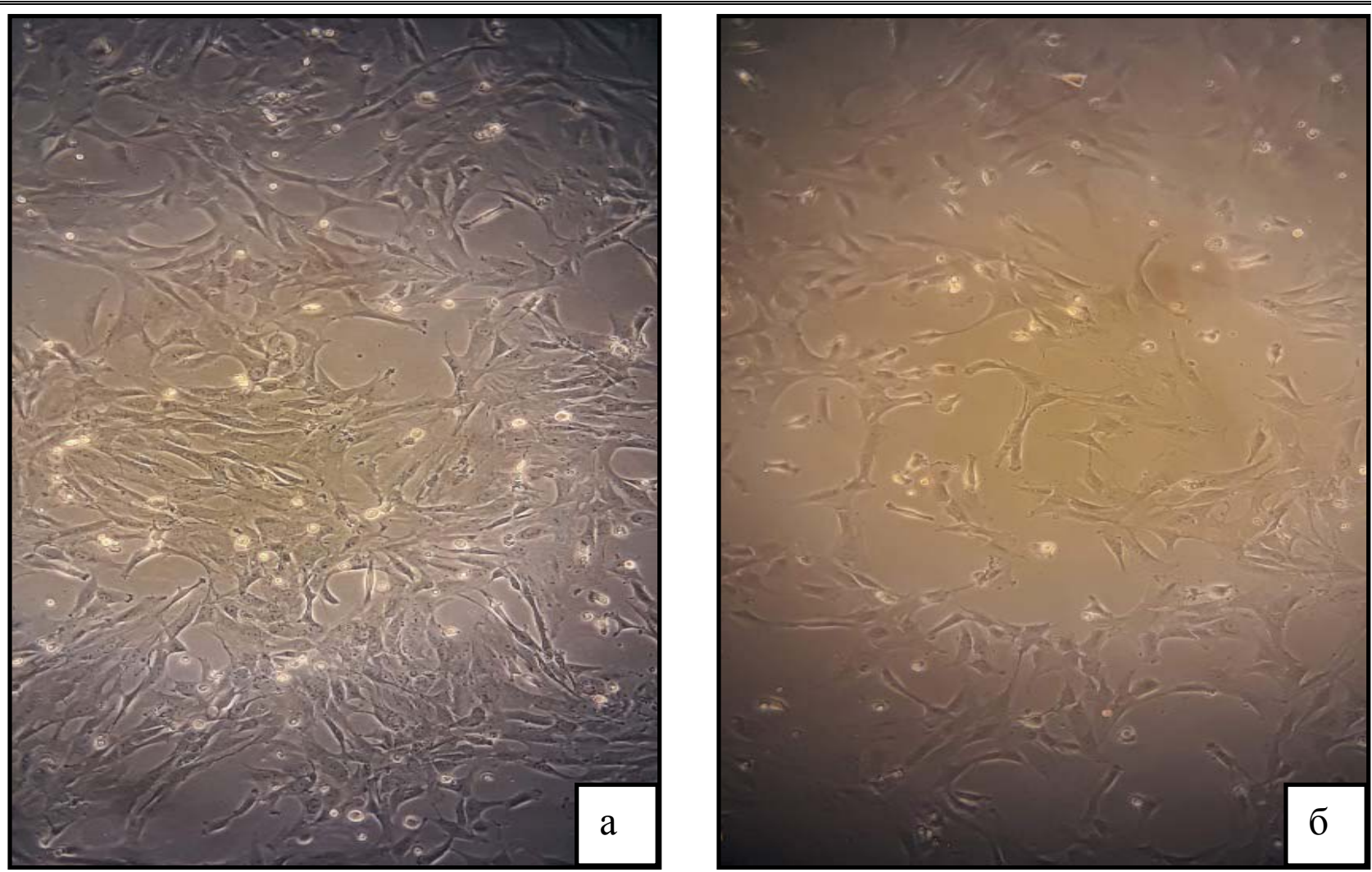

Рис. 1. Мікрофотографії культур стовбурових клітин кісткового мозку за впливу: а) 10 нг/мл rhGH; б) контроль (нативні препарати, х100).

\section{2. Проліферативна активність культур стовбурових клітин різного походження за додавання у культуральне середовище Biolaminin $521 \mathrm{LN}(\mathrm{M} \pm m, n=3)$}

\begin{tabular}{|l|c|c|}
\hline \multirow{2}{*}{ Культура клітин } & LN521 & Контроль \\
\cline { 2 - 3 } & \multicolumn{2}{|c|}{ Індекс проліферації } \\
\hline КСККМ & $1,88 \pm 0,05^{* * *}$ & $1,44 \pm 0,05$ \\
\hline КСКЖТ & $2,35 \pm 0,12^{*}$ & $1,85 \pm 0,11$ \\
\hline КСКМ & $3,07 \pm 0,08^{* * *}$ & $1,81 \pm 0,10$ \\
\hline
\end{tabular}

Примітка: *p<0,05; ***p<0,001 порівняно з контролем

Гормон росту має прямий вплив на велику кількість тканин, адже рецептори до гормону росту (GHR) представлені на м'язовій та жировій тканині [10], проте на клітинах кісткового мозку вони не виявляються [13].

Biolaminin 521 LN мав позитивний вплив на всі досліджувані культури клітин. Так, індекс проліферації для КСККМ та КСКЖТ зріс у 1,3 рази; для КСКМ - у 1,7 разів (табл. 2). Варто зазначити, що за використання LN521 відмічали швидке прикріплення клітин до культурального пластику та сильне їх розпластування. Окрім того, у даній групі чашок моношар 90-100 \% утворився найшвидше (рис. 2).
Biolaminin 521 LN - субстрат на основі рекомбінантного ламініну 521 людини. За даним виробника, даний субстрат позитивно впливає на стабілізацію та гомогенізацію клітинної культури. Через взаємодію з відповідними рецепторами клітинної поверхні, ламініни активують сигнальні каскади (наприклад, PI3K / Akt шлях), забезпечуючи прогнозовану відповідь клітин та поліпшеня їх функціональності. Завдяки LN521 клітини ростуть у однорідному моношарі, що легко контролювати, зберігаючи плюрипотенцію та генетичну цілісність [12]. Заявлені виробником властивості LN521 були підтверджені нами у досліді. 

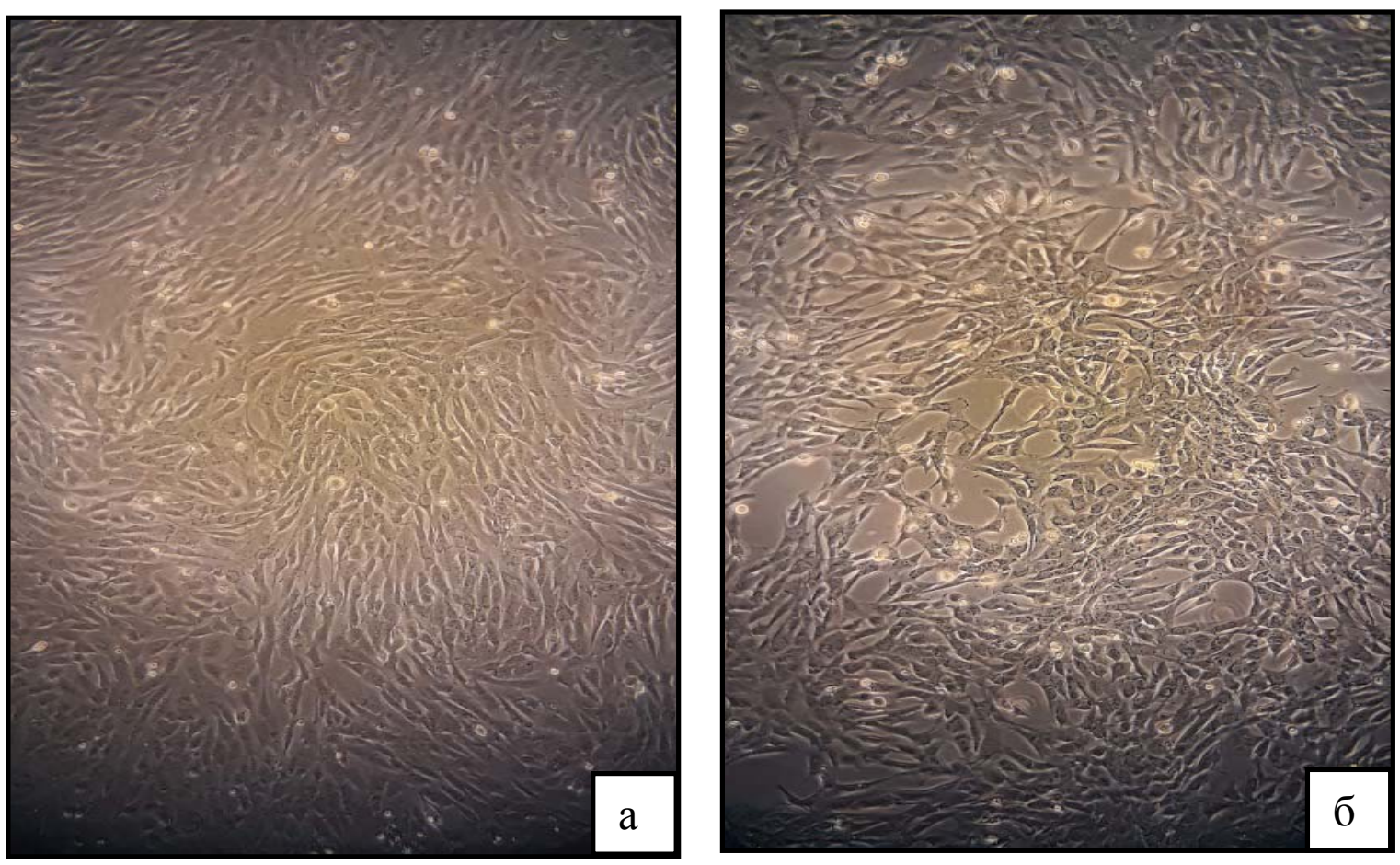

Рис. 2. Мікрофотографї̈ культур стовбурових клітин міокарда за впливу:

a) LN521; б) контроль (нативні препарати, х100).

3. Результати цитогенетичного аналізу культур клітин кота за впливу rhGH ma LN521 (M $\pm m, n=3)$

\begin{tabular}{|l|c|c|c|}
\hline \multirow{2}{*}{ Культура клітин } & rhGH, 10 нг/мл & LN521 & Контроль \\
\cline { 2 - 4 } & \multicolumn{3}{|c|}{ Нормальний каріотип, \% } \\
\hline КСККМ & $78,7 \pm 0,9$ & $83,3 \pm 0,9^{*}$ & $79,3 \pm 0,9$ \\
\hline КСКЖТ & $86,7 \pm 0,9$ & $92,0 \pm 1,3$ & $88,7 \pm 0,8$ \\
\hline КСКМ & $88,7 \pm 1,8$ & $94,0 \pm 0,0^{*}$ & $90 \pm 1,3$ \\
\hline
\end{tabular}

Примітка: *p<0,05 порівняно з контролем
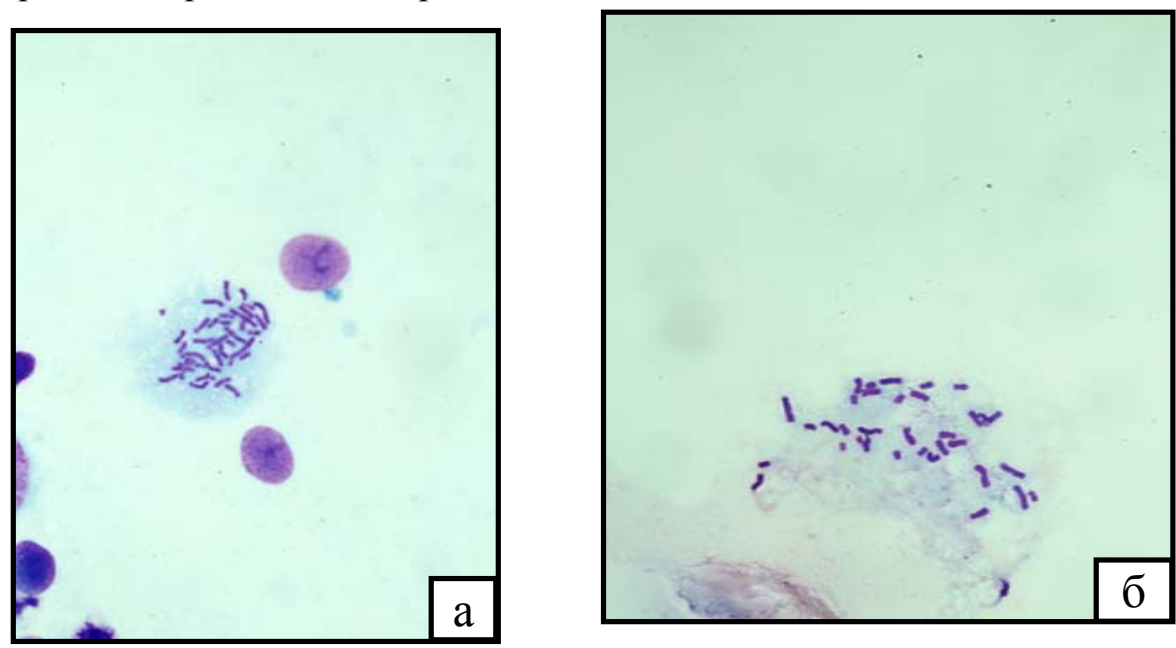

Рис. 3. Мікрофотографії метафазних пластинок клітин кота: а) нормальний каріотип, $n=38$; б) анеуплоїдія, $n=35$ (фарбування «Лейкодиф 200», х1000). 
Для подальшого використання стовбурових клітин у клінічній практиці необхідно підтвердження iii генетичної стабільності. Оскільки прискорення проліферації може призвести до збільшення кількості генетичних помилок у культурі, нами було вирішено додатково провести цитогенетичний аналіз досліджуваних культур клітин 3 найвищим індексом проліферації (табл. 3, рис. 3).

За даними цитогенетичного аналізу, додавання гормону росту у культуральне середовище не призводило до достовірного збільшення кількості генетичних помилок (у порівнянні з контролем) у всіх досліджуваних культурах. Водночас, застосування LN521 призводило до достовірного зниження кількості генетичних помилок у досліджуваних культурах порівняно з контролем, що ще раз підтверджує його властивості, заявлені виробником.

\section{Висновки:}

1. Оптимальна концентрація гормону росту у живильному середовищі для культури стовбурових клітин жирової тканини та міокарда стано-

\section{БІБЛІОГРАФІЯ}

1. Бобось О. Л. Експериментальне обгрунтування ефективності застосування стовбурових клітин для корекції патологічно змінених тканин нирки у дрібних домашніх тварин: дис. ... канд. вет. наук / О. Л. Бобось. - Київ, 2013. -162 с.

2. Бочков Н. П. Клеточная терапия в свете доказательной медицины / Бочков Н.П. // Клиническая медицина. - 2006. - № 10. - С. 4-7.

3. Журба B. I. Науково-експериментальне обгрунтування ефективності застосування стовбурових клітин для відновлення патологічно зміненого суглобового хряща у тварин: дис. ...канд. вет. наук / В. І. Журба. - Київ, 2013. $130 \mathrm{c}$.

4. Золтан Н. I. Експериментальне обгрунтування ефективності застосування стовбурових клітин для корекції патологічно змінених тканин печінки у дрібних домашніх тварин: дис. ... канд. вет. наук / Н. І. Золтан. - Київ, 2013. $144 \mathrm{c}$.

5. Ковпак В. В. Біологічна властивість стовбурових клітин залежно від способу їх отримання та видової належності: дис. ... канд. вет. наук / В. В. Ковпак. - Київ, 2010. - 146 с.

6. Мазуркевич А. Й., Ковпак В. В., Данілов В. Б. Клітинні технології у ветеринарній медицині // Навчальний посібник - К. : КОМПРИНТ. - 2014. $-132 \mathrm{c}$.

7. Bearzi C. Human cardiac stem cells / C. Bearzi, M. Rota, T. Hosoda et al // Proc Natl вить 10 нг/мл, що призводить до збільшення індексу проліферації у 1,2 та 1,3 рази відповідно.

2. При додаванні гормону росту до культури клітин кісткового мозку збільшується розмір клітин та знижується індекс проліферації у порівнянні з контролем.

3. Biolaminin $521 \mathrm{LN}$ має позитивний вплив на всі досліджувані культури клітин. Так, індекс проліферації для КСККМ та КСКЖТ зріс у 1,3 рази, для КСКМ - у 1,7 разів.

4. За даними цитогенетичного аналізу, додавання гормону росту у культуральне середовище не призводить до достовірного збільшення кількості генетичних помилок (у порівнянні 3 контролем) у всіх досліджуваних культурах.

5. Культивування культур стовбурових клітин за додавання Biolaminin $521 \mathrm{LN}$ викликає зменшення кількості клітин зі зміненим каріотипом.

Результати, отримані у процесі дослідження, у подальшому будуть використані для впровадження клітинних технологій у ветеринарну практику.

Acad Sci U S A. - 2007. - №104 (35). - P. 1406814073.

8. Chen $J-Y$. In vitro effects of recombinant human growth hormone on growth of human gastric cancer cell line BGC823 cells / J-Y. Chen, D-M. Liang, P. Gan et al // World Journal of Gastroenterology. - 2004. - №10(8). - P. 1132-1136.

9. Costoya J. A. Activation of growth hormone receptor delivers an antiapoptotic signal: evidence for a role of Akt in this pathway / J. A. Costoya, J. Finidori, S. Moutoussamy // Endocrinology. - 1999. - №140(12). - P. 5937-5943.

10. Frick G. P. Tissue distribution, turnover, and glycosylation of the long and short growth hormone receptor isoforms in rat tissues / G. P. Frick, L. R. Tai, W. R. Baumbach // Endocrinology. - 1998. №139. - P. 2824-2830.

11. Hima Bindu A. (2011) Potency of Various Types of Stem Cells and their Transplantation / A. Hima Bindu, B. Srilatha // J Stem Cell Res Ther. - 2001. - № 1. - P. 115.

12. http://www.biolamina.com/laminin-ln-521stem-cell-matrix

13. https://www.proteinatlas.org/

ENSG00000112964-GHR/tissue/bone+marrow

14. Ian Freshney R. Culture of animal cells: a manual of basic technique / R. Ian Freshney. - [5th ed.] - USA: John Wiley \& Sons. - 2005. - 642 p.

15. Han $J$. Adipose tissue is an extramedullary reservoir for functional hematopoietic stem and pro- 


\section{ВЕТЕРИНАРНА МЕДИЦИНА}

genitor cells / J. Han, Y. J. Koh, H. R. Moon et al // Blood. - 2010. - №115. - P. 957-964

16. Lanza R. Handbook of stem cells / R. Lanza. vol.1. - Amsterdam: Elsevier Inc. - 2004. - 1760 p.

17. Mahmoudifar N. Mesenchymal stem cells derived from human adipose tissue / N. Mahmoudifar, P. M. Doran // Methods Mol Biol. - 2015. №1340. - P. 53-64.

18. Nolan D. J. Bone marrow-derived endothelial progenitor cells are a major determinant of nascent tumor neovascularization / D. J. Nolan, A. Ciarrocchi, A. S. Mellick et al // Genes Dev. - 2007. №21(12). - P. 1546-1558.

19. Pontikoglou C. Bone marrow mesenchymal stem cells: biological properties and their role in hematopoiesis and hematopoietic stem cell transplantation / C. Pontikoglou, F. Deschaseaux, L. Sensebŭ et al // Stem Cell Rev. - 2011. - №7(3). - P. 569-89.

20. Sengenus $C$. Preadipocytes in the human subcutaneous adipose tissue display distinct features

\section{ANNOTATION}

Mazurkevych A. Y., Kovpak V. V., Kovpak O. S. Influence of growth hormon (rhGH) and Biolaminin $521 \mathrm{LN}$ on proliferative activity of stem cells of cat.

The usage of cell technology in clinical practice requires a large amount of cell material. It in turn provokes the development of methods that will allow to obtain a greater amount of cell material for a much shorter period of time. According to literary sources it is known that the growth hormone and the Biolaminin LN 521 can have a positive influence on the mitotic activity of stem cells.

Considering the differences in the cell composition of the cell cultures obtained from different tissues, the effects of recombinant human growth hormone (rhGH) and Biolaminin $521 \mathrm{LN}$ will be different.

Therefore, our aim was to study the effects of recombinant human growth hormone $(\mathrm{rhGH})$ in various concentrations and to study the Biolaminin LN 521 for the proliferative activity of stem cells obtained from bone marrow, adipose tissue and cardiac muscle of cat. from the adult mesenchymal and hematopoietic stem cells / C. Sengenus, K. Lolmude, A. Zakaroff-Girard // J Cell Physiol. - 2005. №205(1). - P. 114-122.

21. Waters M.J. Growth hormone and cell growth / M. J. Waters, A. J. Brooks // Endocr. Dev. - 2012. - №23. - P. 86-95.

22. Wiedemann A. Induced pluripotent stem cells generated from adult bone marrowderived cells of the nonhuman primate (Callithrix jacchus) using a novel quad-cistronic and excisable lentiviral vector / A. Wiedemann, K. Hemmer, I. Bernemann // Cell Reprogram. - 2012. - №14(6). - P. 485-96.

23. Xue $S$. Functional endothelial progenitor cells derived from adipose tissue show beneficial effect on cell therapy of traumatic brain injury / S. Xue, H. T. Zhang, P. Zhang // Neurosci Lett. 2010. - №473(3). - P. 186-191.

The effects of recombinant human growth hormone $(\mathrm{rhGH})$ in various concentrations and the effects of Biolaminin LN 521 for proliferative activity and genetic stability of stem cells obtained from bone marrow, adipose tissue and cardiac muscle of cat were studied. It was found that the growth hormone has a positive effect on the proliferative activity of stem cells in cell cultures of adipose tissue and cardiac muscle of cat at low concentrations $(10 \mathrm{ng} / \mathrm{ml})$, while the effect on the cell culture of bone marrow stem cells was the opposite. According to the cytogenetic analysis it was found that adding recombinant human growth hormone to the culture media does not lead to a significant increase in the number of genetic errors, while adding the Biolaminin 521 LN leads to a decrease in the number of cells with altered karyotype (in comparison with control) in all the studied cell cultures.

Key words: recombinant human growth hormone (rhGH), Biolaminin $521 \mathrm{LN}$, stem cells, bone marrow cell culture, adipose tissue cell culture, cardiac muscle cell culture, cats, cytogenetic analysis. 